\title{
A geological interpretation of geophysical self-potential anomalies in the Radzimowice ore district, Sudetes, south-western Poland
}

\author{
Jerzy Sobotka, Marzena Farbisz-Michałek \\ University of Wrocław, Institute of Geological Sciences; pl. Maksa Borna 9,50-204 Wrocław, Poland; \\ e-mail: jerzy.sobotka@uwr.edu.pl,m.farbisz@gmail.com
}

(C) 2016 Authors. This is an open access publication, which can be used, distributed and reproduced in any medium according to the Creative Commons CC-BY 4.0 License requiring that the original work has been properly cited.

Received: 2017-02-06; accepted: 2017-03-01

\begin{abstract}
The analysis of the geophysical surveys results carried out in the Radzimowice area reveals that the anomalous zones of significant SP (self-potential) anomalies of natural SP fields do not substantially find a reflection in existing geological papers. Confrontation of existing geological elaborations with the results of SP analysis shows that the selfpotential studies expose significant elements of geological setting - i.e. run of faults, lithological boundaries, occurrence of ore mineralization - which can be helpful in clarifying the geological setting of the area. In the study, archived self-potential data were used and additionally new SP measurements were executed to justify their treatment as a valuable source of information.
\end{abstract}

Keywords: Radzimowice ore district, self-potential method, SP anomalies, ore mineralization, graphite body, prospecting of ore deposits

\section{INTRODUCTION}

The self-potential (SP) method is one of the oldest geophysical methods used to recognize the geological structure not accessible to direct observations (Ogilvy et al. 1989). It was first applied in 1830 by Robert W. Fox, who measured the potential between two copper-plate electrodes to detect ore mineralization within Cornish deposits in Great Britain (Reynolds 1997). After almost 100 years, the phenomena of naturally occurring electric potential was recognized again as an effect of ground water flow in a porous medium. Thus, the method started to be widely applied not only in geological prospecting and the exploration of ore deposits but also in the oil and gas industry (Revil et al. 2004, Sobotka 2005). Nowadays, the self-potential method is still frequently applied in well logging and ore mineralization prospecting as well as to determine and monitor water circulation in karst, dams, volcanoes or migration of contaminants.

The south-western part of Poland (Sudetes Mts.) belongs geologically to the Bohemian Massif, the large outcrop of Variscan basement in central Europe. In many places in the Sudetes, ore mineralization occurs, and the small deposits of arsenic, copper, silver and gold have been mined since Medieval times (e.g. Mikulski 1999, 2005). These deposits are exhausted now, but efforts to find new ones are undertaken repeatedly. For this reason, geophysical surveys, especially SP measurements, conducted in the 1950s and 60s in many areas of Sudetes focused on the identification of perspective ore mineralization zones. One of the most promising areas 
was the Radzimowice ore district where zones with an increased concentration of metals were found.

The SP data from Radzimowice ore district should belong to the most interesting results, where numerous intensive negative anomalies, up to $-800 \mathrm{mV}$, were observed. The interpretation of the SP survey results shows that such an outstanding intensive SP anomalies can be caused by graphite bodies, a graphite substance disseminated within rocks or rich sulfide ore mineralization. Nevertheless, no efforts have been undertaken in order to explain the reasons for the SP anomalies and their relationship to the ore mineralization. Since the example of Radzimowice is interesting because of both its methodical approach and the potential possibility of ore mineralization discovery, we discuss it in this paper.

\section{GEOLOGICAL SETTING}

The self-potential measurements were carried out in the south-eastern part of the Kaczawa Mountains in the Sudetes (Fig. 1). The Sudetes are the north-eastern margin of the Bohemian Massif, the easternmost outcrop of the Variscan crystalline basement in Europe (Fig. 1).

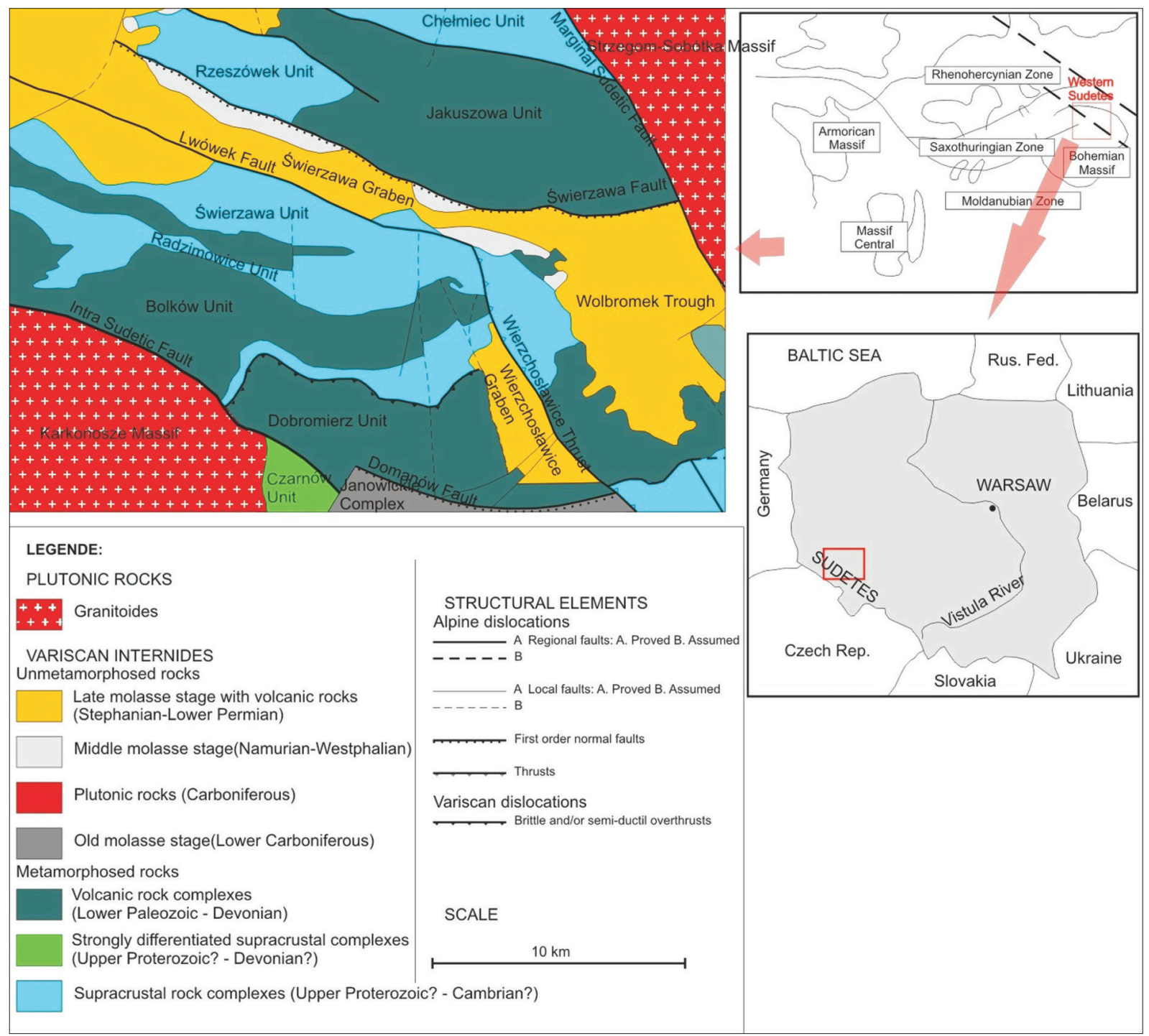

Fig. 1. Location of Radzimowice unit relative to tectonic units of the Kaczawa Complex on the tectonic map of Sudetes and ForeSudetic Block (after Cymerman 2004, Mikulski 2007) 


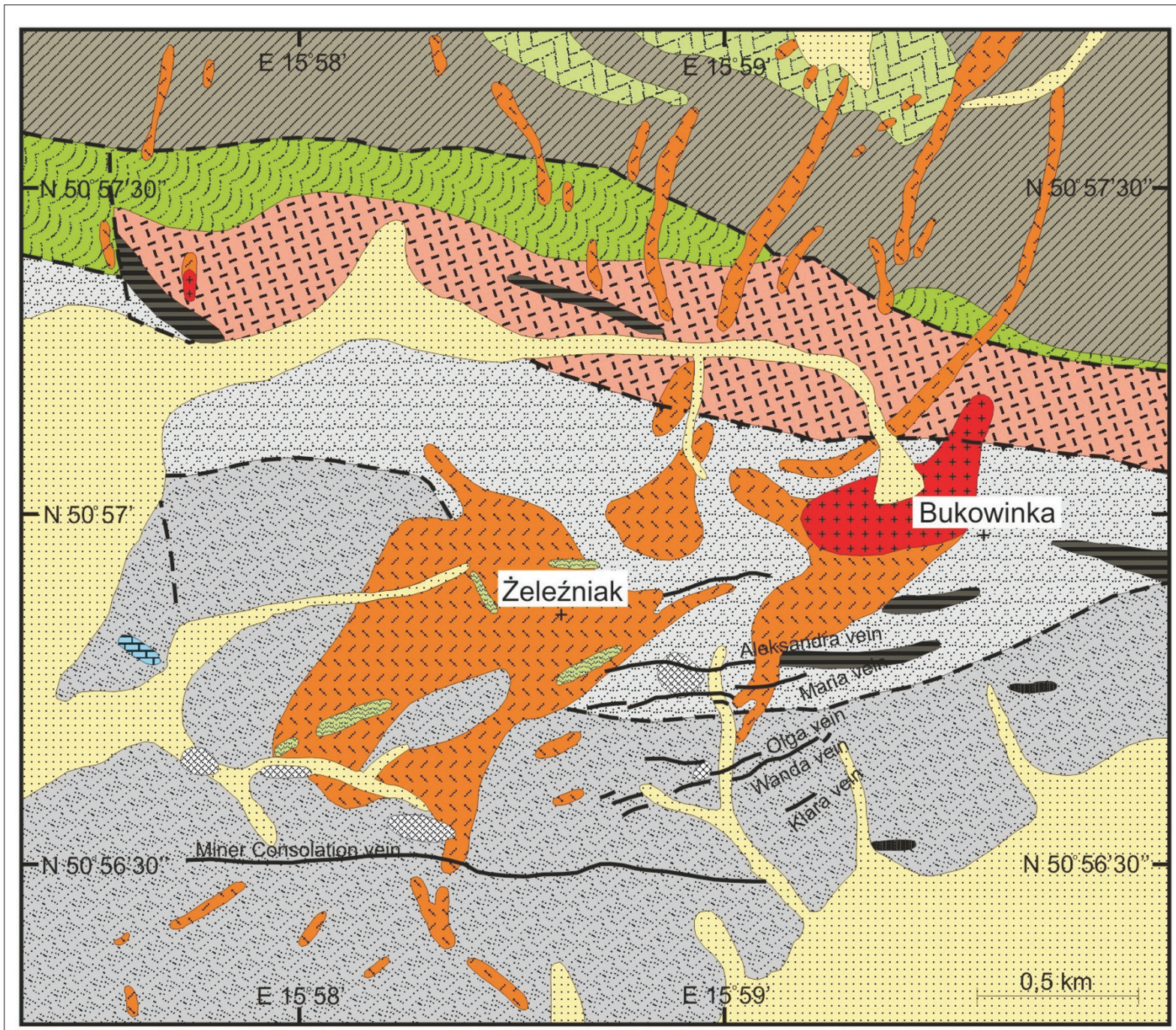

\section{Legende:}

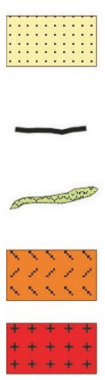

Pleistocene (undivided)

Quartz-sulphide vein

Andesite dyke

Dacite porphyry (C)

Granite $\left(\mathrm{C}_{2}\right)$

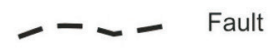

メ $\mathbf{-}$ Thrust (acc. To Teisseyre, 1967)

res

Remnants of mining activities:shaft, dump

\section{Radzimowice Schists unit}

Quartz-sericite schists with lenses of graphite and siliceous schist, minior graywacke greenstone or crystalline limestone $\left(\right.$ ? $\left.\mathrm{Cm} / \mathrm{O}-\mathrm{C}_{1}\right)$

Graphite and siliceous schists (S)

Crystalline limestone or dolostone $\left(\mathrm{S}-\mathrm{C}_{1}\right)$

Chmielarz schists: sericite and sericite-chlorite schists with interbedded lenses of masive greenstone and siliceous schist (?Cm/O- $\left.\mathrm{C}_{1}\right)$

\section{Świerzawa unit}

군 Metatuff and metatuffite with

ㄴ. $\div$ interbedded inserts of siliceous schist

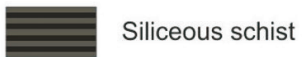

Aphyric greenstone, locally strongly foliated with phyllite layers

Sericite-quartz schist with quarzite lenses

Phyllite

Fig. 2. Geological map of the Radzimowice area (Mikulski 2007 after: Baranowski 1988, Kryza \& Muszyński 1992, Cwojdzińsk \& Kozdrój 1994, Paulo \& Salamon 1974) 
The Kaczawa Mountains consist of two structural sequences: the upper one (late Permian-Mesosoic) and the lower one called the Kaczawa Metamorphic Complex (Kryza \& Muszyński 1992). The latter is subdivided into smaller scale tectonic units, consisting of metasedimentary and metavolcanic rock series ranging in age from the early Cambrian (possible Neoproterozoic) to early Carboniferous (Kryza \& Zalasiewicz 2008), metamorphosed during Variscan orogeny in late Devonian and early Carboniferous times.

The metamorphic grade is low (Kryza \& Zalasiewicz 2008).

The results of the SP measurements come from the Radzimowice Unit (more precisely its eastern part) - defined by Baranowski et al. (1990) as a separate thrust sheet of the Kaczawa Metamorphic Complex (Fig. 1). Several rock formations occur within the Radzimowice Unit. The largest ones are the Chmielarz slates in the north and the Radzimowice slates in the south (Fig. 2) (Baranowski 1988).

The Chmielarz slates are sericite and sericitechlorite slates with interbedded lenses of massive greenstone and silicic schists of Cambrian or Ordovician to early Carboniferous age (Baranowski 1988). The Radzimowice slates are mainly comprised of dark sericite-quartz-albite phyllites (Baranowski 1988). Their characteristic feature is disseminated graphite which occurs in different amounts (Manecki 1962, Baranowski 1988 and references therein). Lenses of Silurian graphite and silicic schists and Silurian to early Carboniferous crystalline limestones or dolostones occur within the Chmielarz and Radzimowice slates (Fig. 2; Baranowski 1988).

An important element of the geological setting of the Radzimowice Unit are polymetallic ore veins, which form the Radzimowice $\mathrm{Au}-\mathrm{As}-\mathrm{Cu}$ ore district (Fig. 2). It is situated in the eastern part of the Radzimowice unit and is genetically connected to the Variscan dacite intrusion of the Żeleźniak, belonging to the Żeleźniak Igneous Complex (Fig. 2; Skurzewski 1984, Kozdrój 1995). The complex consists of granite (Bukowinka Hill), porphyries (Żeleźniak Hill) and lamprophyres (Fig. 2; Mikulski 2007). Within the Żeleźniak dacite intrusion and its wallrocks, ore mineralization occurs. It is mostly concentrated in almost vertical quartz sulfide-carbonate veins departing from the Żeleźniak intrusion (Mikulski 2007). The main ore minerals are Co-arsenopyrite, pyrite, chalcopyrite, sphalerite and galena.

\section{SP METHOD PRINCIPLES}

The self-potential (SP) method belongs to passive geoelectric methods and measures naturally occurring voltage between two points on the ground. The appearance of natural electric fields in the ground is associated with different types of source mechanisms related to electrokinetic and electrochemical processes occurring in the subsurface and causing the formation of electrofiltration, thermoelectric, electrochemical and mineralization potentials (e.g. Sharma 2002). Hence the value of SP is usually the sum of different potential types given above (e.g. Reynolds 1997).

Natural currents generate SP anomalies which can achieve up to several hundreds of millivolts. Furthermore, values that are different than $0 \mathrm{mV}$ are considered as positive or negative anomalies (e.g. Reynolds 1997). The self-potentials are produced by different natural sources i.e. sulfides massive ores, graphite bodies, ferromagnetic minerals, coals and water circulation (outflow) which generates negative SP anomalies of hundreds of millivolts. On the other hand, quartz veins, pegmatites, groundwater movements (inflow) appear as positive SP anomalies ranging from tens to hundreds of millivolts. However, the geometry of the structure and volume of the source and occurrence of different overlapping factors might result in an SP value (Reynolds 1997).

Typical field equipment usually consists of a digital multimeter, a pair of non-polarized electrodes and a copper wire. The SP method can be applied in two versions - gradient mode and potential mode. In the gradient mode, a pair of separated electrodes move simultaneously along a profile line (the distance between electrodes " $\mathrm{M}$ " and " $\mathrm{N}$ " is invariable). Whereas the potential mode assumes a stable electrode ("M") and moving one ("N") along the profile for fixed interval, however, the distance between both electrodes cannot exceed more than $300 \mathrm{~m}$ due to the influence of telluric currents for longer distances. 


\section{ARCHIVE SP DATA AND CONTROL SP MEASUREMENTS}

The studied part of the Radzimowice unit is covered by 28 SP profile lines oriented N-S with a total length of ca. $60 \mathrm{~km}$ (Fig. 3) which were executed in the 1950s and 60s by the Geophysical Exploration Company (PBG). The SP measurements were acquired with $10 \mathrm{~m}$ electrode interval using the potential mode of the SP method. The geological exploration works were carried out by Polish Geological Institute in order to identify interesting zones of polymetallic ore mineralization occurrence in Sudetes.

Archive data, especially those from more than 50 years, often raise many doubts about their credibility and possibility of interpretation. In order to verify the archive SP data from the Radzimowice area on selected sections of archive profiles, control SP measurements were executed.

During field measurements, special equipment consisting of the author's digital multimeter, a pair of non-polarized electrodes and 300-meter copper wire were used. The major goal of the gauge was to get an average value of SP for each measured point with the possibility to change different parameters such as: amount of measurements (from 1 to 5 per second), time of measure (1-30 sec) and error range (extreme values are rejected depending on user settings). In general, self-potential was measured during $30 \mathrm{sec}$, with frequency of 5 measures per second, which gave an average of 150 measures for one point. The gauge had also the possibility to check the number of rejected measures, which showed the noise range - more rejected measures are evidence of high level of noises.

Control SP measurements were executed in the same mode as the archive ones. Measurements were made along the segments of archive profiles no longer than $300 \mathrm{~m}$. The location of each tested profile was set using a GPS system.

During field works, nine profiles with a length of $300 \mathrm{~m}$ and one profile with a length of $600 \mathrm{~m}$ were executed (in sum, $3000 \mathrm{~m}$ ).

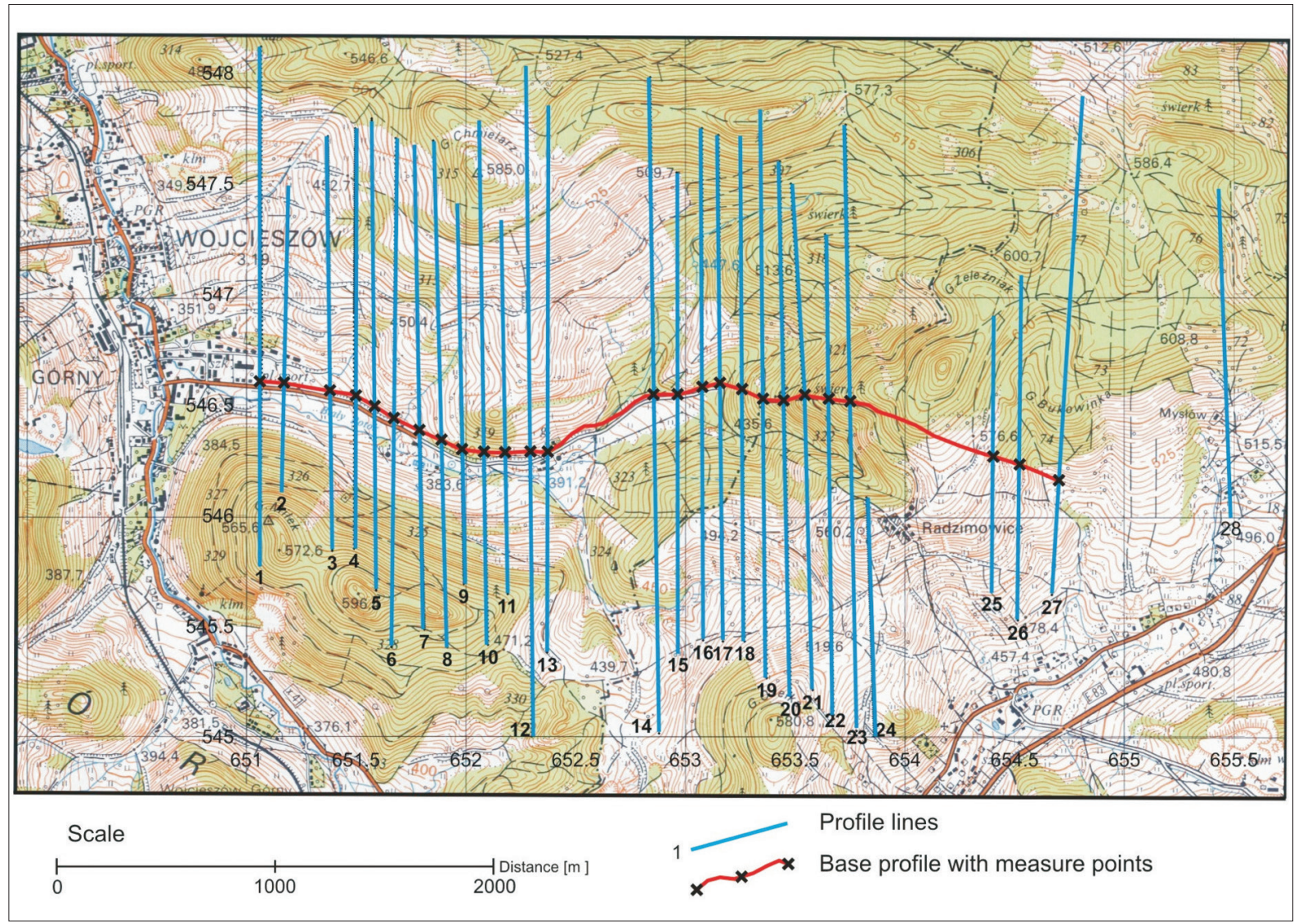

Fig. 3. Topographic map of the Wojcieszów - Radzimowice area (Bolków sheet) with location of archive SP measurements, controlled SP measurements and the base profile 
Additionally, a base profile was made with a total length $4000 \mathrm{~m}$ (Fig. 3) which consisted of a section of 200-300 m connected to each other with 3 footholds. Average measuring interval was $50 \mathrm{~m}$ but in every crossing of the base profile with the perpendicular profile, additional measures were executed.

Control SP measurements completely confirmed the reliability of the archive SP data and justified their treatment as a valuable database. Considering the results of the base profile, all SP values were standardized to one reference point. With help of Didger software, coordinates were established in a local reference system. The field data was summarized and became the basis for the creation of new SP contour maps.

\section{INTERPRETATION OF SP CONTOUR MAPS}

Basing on the gathered data, several versions of SP maps were prepared using different grid interpolations which illustrated the distribution of SP anomalies, the borders, discontinuities and lateral disorders as well as extremes of natural SP. Analyzing the distribution of the SP field (Fig. 4) the anomalous zone extending NW-SE with a width of approximately $1700 \mathrm{~m}$ can be clearly noticed. This zone is sharply bounded from NE and SW and marked on the map as straight purple lines, parallel to each other. Within the discussed zone, some lateral disorders reveal themselves as displacements of anomalous sequences and a series of linearly stacked zones of positive and negative anomalies. Those lines of displacement are arranged along SW-NE and S-N directions (Fig. 4). Moreover, within the anomalous zones several extremely negative SP values (below $-200 \mathrm{mV}$ ) can be distinguished (Fig. 4).

\section{GEOLOGICAL INTERPRETATION OF SP ANOMALIES}

In order to carry out the geological interpretation of SP anomalies, the elaborated maps were compared with the geological map of the Wojcieszów - Radzimowice area (Wojcieszów sheet of the detailed geological map of Sudetes in 1:25 000 scale) (Cwojdziński \& Kozdrój 1994).
A superimposed image of the regional borders of SP anomalies on the geological map of the Radzimowice area is presented in Figure 5. Such a comparison shows some similarities between the designated elements of the SP field with the geological map - several regional trends correspond with the borders of the occurrence of Radzimowice slates on the geological map but in some places, we can see discrepancies.

Considering the geological origins of natural potentials, the sources of such outstanding SP anomalies should be seen in the petrological content of the Radzimowice slates, especially as the effect of graphite factor occurrence, which generates significant SP anomalies (e.g. Reynolds 1997). In this case, the extent of the SP anomalies zone should be considered as the borders of disseminated graphite matter within the Radzimowice slates, the amount of which increases in the central part of the anomalous zone. However, the intensity of the SP anomaly shows that within the Radzimowice slates the contribution of graphite is significant and it has to be much higher than found in the previous studies of this area. Local extreme SP anomalies are the result of intense graphitization and even greater graphite bodies (Fig. 5), which are highlighted on the geological map of the area by Cwojdziński \& Kozdrój (1994) as Silurian lenses lying within the Radzimowice slates.

The lateral disorders distinguished in Figure 4 and compared with the geological map of the studied region (Fig. 5) should be treated as tectonic zones. The characteristic system of linearly arranged positive and negative anomalies can represent zones of inflow (positive anomaly) and outflow (negative anomaly) of water within respective faults.

The confrontation of SP maps with the geological map indicates that several discontinuous zones in some parts respond to mapped faults (orange lines - Fig. 5). The analysis of SP data points out that these kinds of tectonic zones could be much farther spread out, which is presented by yellow lines as the probable continuation of these zones. Moreover, in Figure 5 the zones with black dash lines, which have no confirmation in the geological map, were pointed out. The parallel direction of discontinuous lines may reflect the existence of a major fault system within the Radzimowice slates exposed in the anomalous distribution of natural potential. 


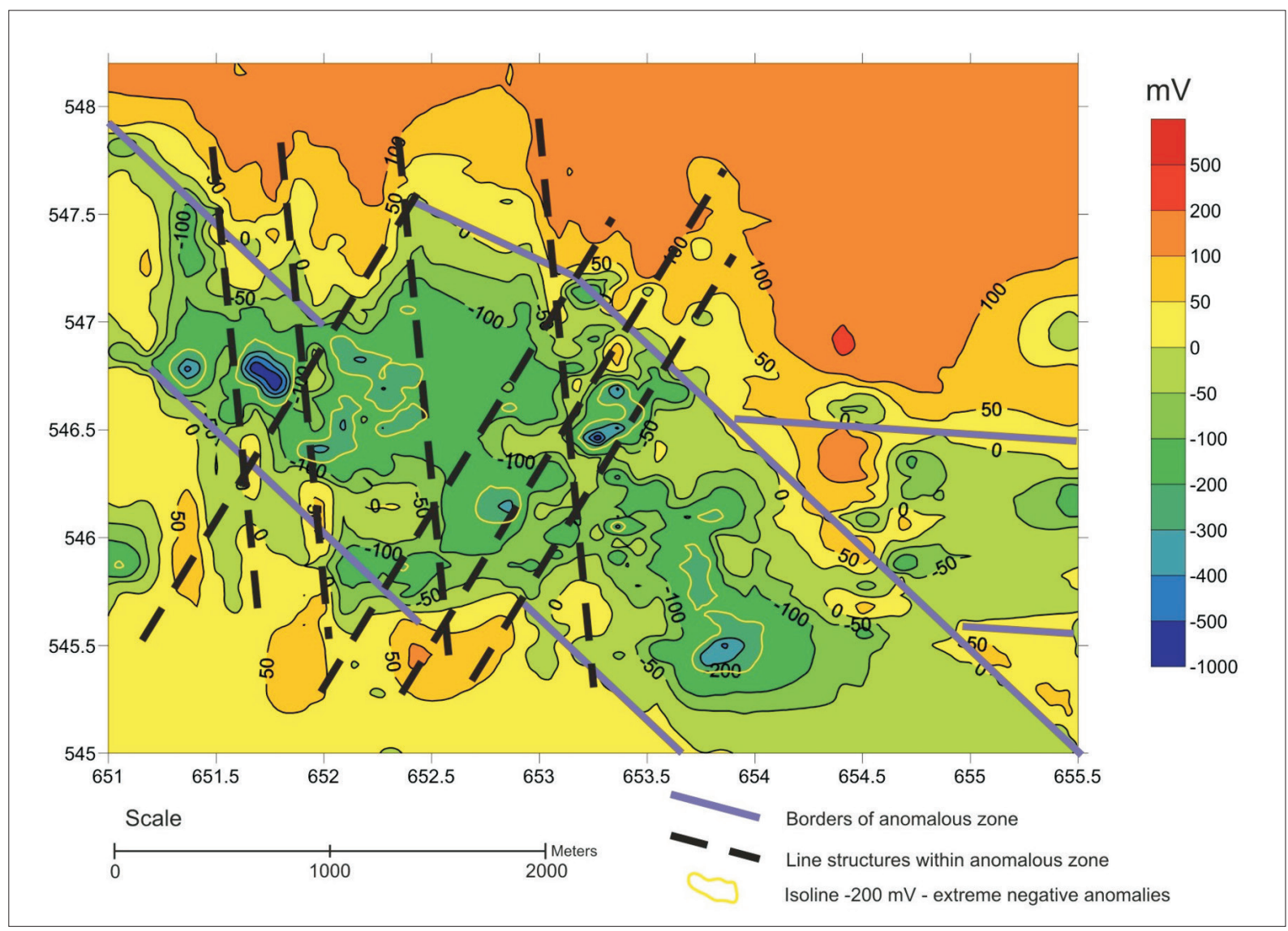

Fig. 4. Lines of discontinuities, lateral disorders, regional borders of anomalous zone and zone of extreme anomalies below $-200 \mathrm{mV}$ basing on map of SP distribution (grid 100/70)

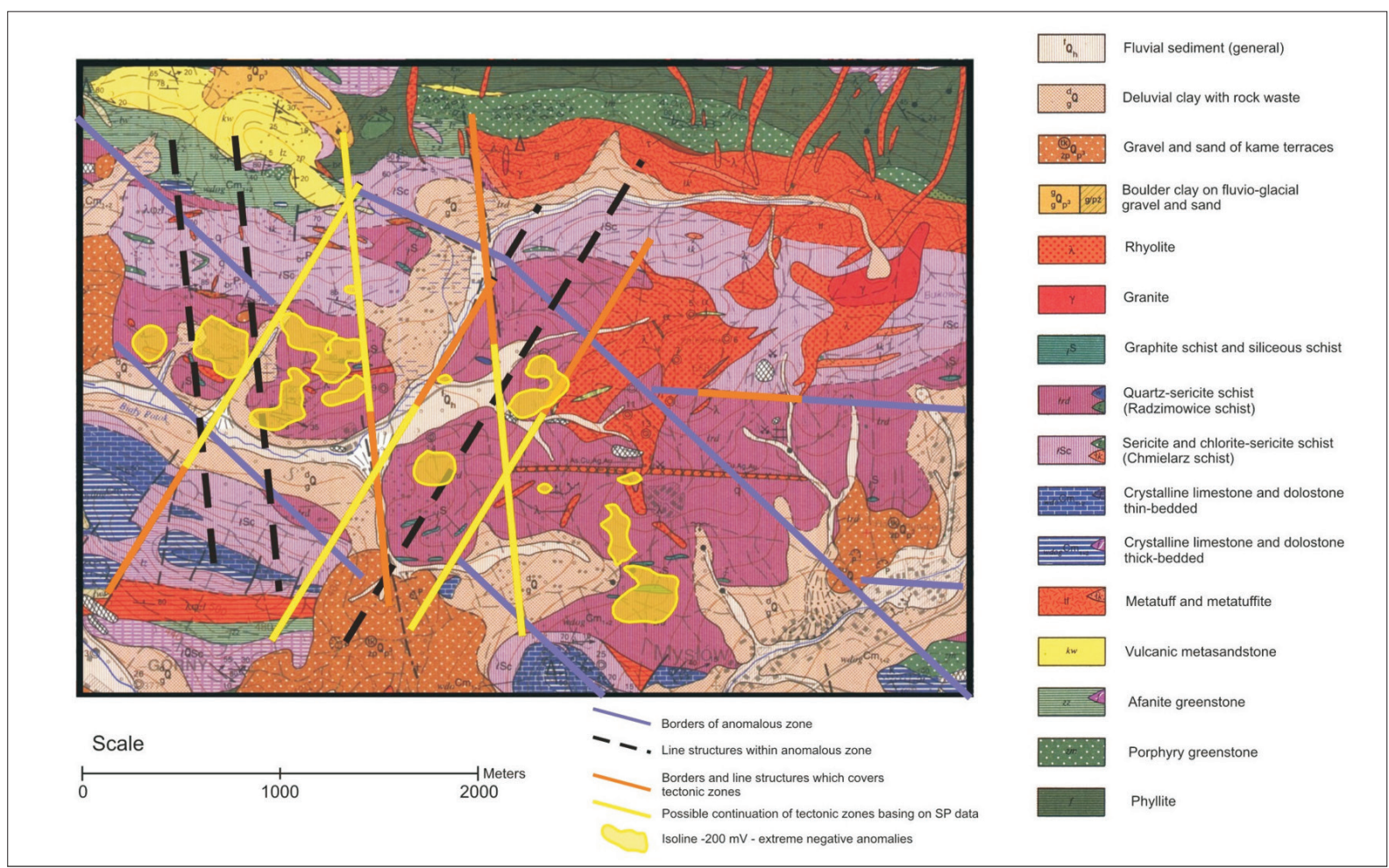

Fig. 5. Borders of the anomalous zone, the extreme anomalies and elements of tectonic interpreted based on SP map presented on the 1:25 000 geological map background of the Radzimowice unit 
To identify the sources of SP anomalies in the lithology of the Radzimowice unit, ore mineralization cannot be overlooked because it is a significant factor generating natural potentials. Moreover, as was mentioned at the beginning of the paper, geophysical surveys were carried out to distinguish ore mineralization in this area. The fundamental work for the SP method, written by Sato and Mooney (1960), explains that the anomalies accompanying ore veins as a general rule do not decrease below $-200 \mathrm{mV}$. In the case of the simultaneous occurrence of ore mineralization and graphitization, which is observed in the Radzimowice unit, strong negative anomalies caused by graphite bodies mask the effects of ore mineralization. It is also possible that both factors overlap in the axial parts of extreme negative anomalies.

In Figure 6 the location of ore veins made by Paulo \& Salamon (1974) is presented on the background of SP map. From this juxtaposition, the extent of the $\mathrm{As}, \mathrm{Cu}, \mathrm{Ag}$, Au polymethalic vein known as "the Miner Consolation" emerges as it is set by SP anomaly lows that are isolated because of the long distances between profiles. The nearest anomalous zone observed on the west from the known part of the vein indicates its farther continuation in this direction. On the profile lines no. 26 (Fig. 6) crosscutting the area of raised value of the SP field, the zone of the Miner Consolation vein and another band of veins is excellently reflected in the SP field by the significant minimums of the SP anomaly.

Ore veins in the central part of profile line no 26 showed on the old miner maps were not recorded, probably because of the too great interval of measurements $(10 \mathrm{~m})$ in relation to their thickness.

Taking into account the correlation of geologically mapped ore veins with SP anomalies on profile line no 26 , the new, previously unexposed zones of ore mineralization in the other part of the Radzimowice unit can be forecast. Prospective SP anomalies occurring in the eastern part are pointed out on Figure 6 with blue contours.

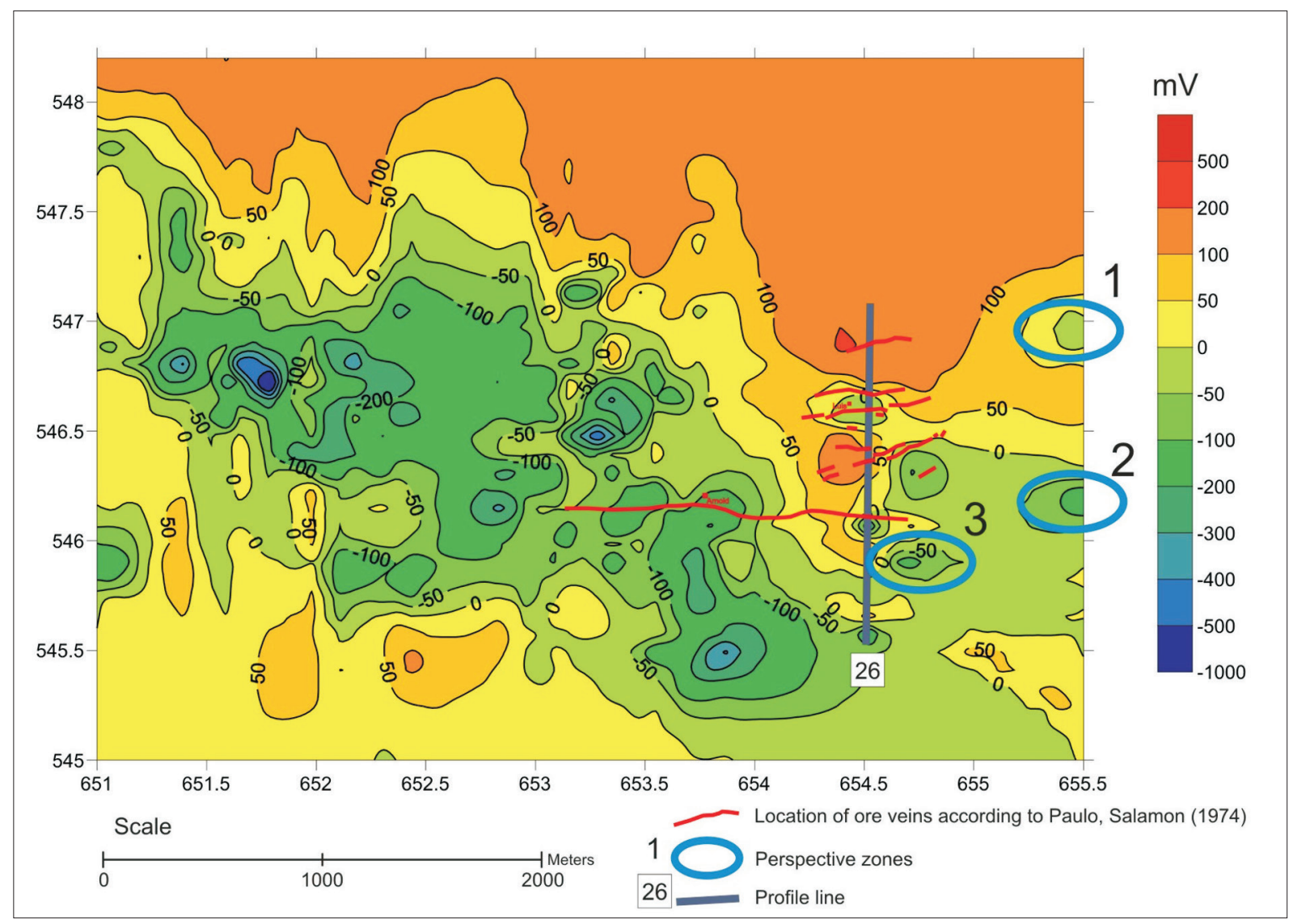

Fig. 6. The location of ore veins made by Paulo \& Salamon (1974) and the prospective zones of ore mineralization occurrence based on the map of SP anomaly 
In the western part, the identification of "ore anomalies" became problematic because of the increased graphitization of rocks. In this case, we propose using other geophysical methods (for example, electromagnetic or induced polarization), which will help to distinguish the anomalies caused by graphitization and those caused by ore mineralization or to affirm the occurrence of both factors.

\section{CONCLUSIONS}

As the result of the verification and reinterpretation of archive SP data, the maps of natural SP field distribution were presented. The analysis of SP surveys results in the Radzimowice unit shows that the significant SP anomalous zones substantially do not find the direct reflection in existing geological studies and papers.

The juxtaposition of the elements revealed in the map of SP anomalies with the DgmS index (a number of minerals of economic and commercial value abound in the country) of the examined area, gives rise to the following issues:

1. The Radzimowice slates might be clarified as a rock sequence with more intensive graphitization (considering SP data), than it is known from previous descriptions, moreover the boundaries of this complex could be identified based on the extension of graphite matter. The borders of the Radzimowice slates, especially their northern range, designated during geological mapping have a putative character. The authors of the Wojcieszów sheet map emphasize that because of the poorly exposed terrain, the contacts of different lithologies are difficult to observe. Moreover, most of the geological mapping in this area was carried out based on studies from weathered zones and analysis of rock fragments from shallow excavations, which can be the reason of significant errors.

The application of the SP method in the geological investigation of the Radzimowice area finds its confirmation in the papers concerning SP method (i.e. Reynolds 1997). The author gives examples of the use of SP measurements in the geological mapping of a rock series which differs only slightly in SP values by several dozen millivolts.
2. The zones of extreme SP anomalies might be interpreted as Silurian lenses of graphite schists within the Radzimowice slates. This statement corresponds with the lithostratigraphic profile elaborated by authors of Wojcieszów sheet and the conceptional geological cross-section for this area. However, the size of the extreme SP anomalies indicates that the graphite bodies within the Radzimowice slates have a greater volume than predicted.

3. The results of SP data interpretation may allow us to supplement the tectonics of studied area with the possible continuation of known, existing fault zones as well as the designation of new faults. Due to the pure exposure of the terrain, most of the tectonic zones marked by Cwojdziński \& Kozdrój on DgmS have a presumed classification. The zones of SP field discontinuities support the assumption of the authors confirming the existence of faults (local tectonic directions) and, moreover, they suggest their continuations. Additionally, the SP surveys helped to distinguish another different (separate) parallel fault zones and, therefore, a more advanced fault system could be expected in Radzimowice area.

4. The analysis of SP maps justifies the question as to how this elaborated data complements knowledge about ore mineralization in the Radzimowice area. As mentioned before, the geophysical surveys of the 1950 s and 60 s were carried out as part of the geological exploration works for ore deposits. The SP results at that time were evaluated as not very promising (Kozdrój 1995), but the current situation, where the prices of ores are very high on global markets, exploitation of poorer ore deposits has become more profitable and the zones of ore mineralization within the Radzimowice slates may become an area of investor interest.

\section{SUMMARY}

The Radzimowice ore district used to be a mining exploration area and after different geophysical surveys carried out in 1952-1953 and 1959, underground mining was stopped. At the time, the obtained results were evaluated as not very promising (Kozdrój 1995), however now, with the prices 
of metals on global markets very high, exploitation of brownfields is becoming more profitable and the Radzimowice ore district may become an area of investor interest.

The confrontation of existing geological studies with the results of SP analysis shows that the results of SP measurements may expose significant elements of a geological setting - i.e. run of faults, lithological boundaries, occurrence of ore mineralization - which can be helpful in specifying the geological setting of this area.

Presented in a new form, the results of SP measurements should be of significant importance to explain the problem of ore mineralization in the Radzimowice unit. Geologically documented (Paulo \& Salamon 1974) ore veins find confirmation on the SP profiles as characteristic anomalies. Similar anomalies, which appear in several other places of the studied area, are pointed out as prospective ore zones which have not been revealed by any geological works.

Within the scope of geological works which will document the resources of ore deposit in the Radzimowice area, we suggest mapping the details of prospective zones of SP anomalies with detailed SP profiling with a measurement interval of $5 \mathrm{~m}$. It would be also necessary to perform additional geophysical measurements using the following methods: geomagnetic, VLF or induced polarization which will allow the recognition of the character of the anomaly, in particular to distinguish "ore anomalies" from "graphite anomalies".

Many thanks are due to PBG Geophysical Exploration Ltd. for the access to archive SP data.

\section{REFERENCES}

Baranowski Z., 1988. Łupki radzimowickie Gór Kaczawskich (Sudety Zachodnie): charakterystyka litofacjalna zmetamorfizowanych osadów rowu oceanicznego. Annales Societatis Geologorum Poloniae, 58, 3-4, 325-383.

Baranowski Z., Haydukiewicz A., Kryza R., Lorenc S., Muszyński A., Solecki A. \& Urbanek Z., 1990. Outline of the Geology of the Góry Kaczawskie (Sudetes, Poland). Neues Jahrbuch für Geologie und Paläontologie. Abhandlungen, 179, 223-257.

Cwojdziński S. \& Kozdrój W., 1994. Szczegółowa mapa geologiczna Sudetów w skali 1: 25 000. Arkusz Wojcieszów. Państwowy Instytut Geologiczny, Warszawa.
Cymerman Z., 2004. Mapa tektoniczna Sudetów i Bloku Przedsudeckiego = Tectonic map of the Sudetes and the Fore-Sudetic Block 1:200 000. Państwowy Instytut Geologiczny, Warszawa.

Kozdrój W., 1995. Objaśnienie do Szczegółowej mapy geologicznej Sudetów 1:25 000. Arkusz Wojcieszów. Państwowy Instytut Geologiczny, Warszawa.

Kryza R. \& Muszyński A., 1992. Pre-Variscan volcanic-sedimentary succession of the central southern Góry Kaczawskie, SW Poland: Outline geology. Annales Societatis Geologorum Poloniae, 62, 117-140.

Kryza R. \& Zalasiewicz J., 2008. Records of PrecambrianEarly Palaeozoic volcanic and sedimentary processes in the Central European Variscides: A review of SHRIMP zircon data from the Kaczawa succession (Sudetes, SW Poland). Tectonophysics, 461, 60-71.

Manecki A., 1962. Grafit w łupkach radzimowickich (okolice Wojcieszowa). Sprawozdania z Posiedzeń Komisji Naukowych - Polska Akademia Nauk. Oddział w Krakowie, $5,1,203-205$

Mikulski S.Z., 1999. Złoto z Radzimowic w Górach Kaczawskich (Sudety) - nowe dane geochemiczne i mineralogiczne. Przegląd Geologiczny, 47, 11, 999-1005.

Mikulski S.Z., 2005. Geological, mineralogical and geochemical characteristics of the Radzimowice Au-As-Cu deposit from the Kaczawa Mountains (Western Sudetes, Poland): an example of the transition of porphyry and epithermal style. Mineralium Deposita, 39, 8, 904-920.

Mikulski S.Z., 2007. The late Variscan gold mineralization in the Kaczawa Mountains, Western Sudetes. Polish Geological Institute Special Papers, 22, Polish Geological Institute, Warszawa.

Ogilvy A., Ostrovskij E. \& Ruderman E., 1989. Electrical surveys using the method of the natural potential electrical field; new investigations. [in:] Merkler G. et al. (eds.), Detection of Subsurface Flow Phenomena, Lecture Notes in Earth Sciences, 27, Springer-Verlag, Berlin Heidelberg, 401-462.

Paulo A. \& Salamon W., 1974. Przyczynek do znajomości złoża polimetalicznego w Starej Górze. Kwartalnik Geologiczny, 18, 2, 266-276.

Revil A., Titov K., Doussan C. \& Lapenna V., 2004. Application of the self-potential method to hydrogeological problems. [in:] Vereecken H. et al. (eds.), Applied Hydrogeophysics, NATO Science Series, IV. Earth and Environmental Sciences, 71, Springer Science \& Business Media, 255-292.

Reynolds J., 1997. An introduction to Applied and Environmental Geophysics. John Wiley \& Sons.

Sato M. \& Mooney H.M., 1960. Electrochemical mechanism of sulfide self-potentials. Geophysics, 25, 1, 226-249.

Sharma V. Prem, 2002. Environmental and Engeenering Geophysics. Cambridge University Press, Cambridge, 190-205.

Skurzewski A., 1984. Wulkanity hercyńskie w rejonie Wojcieszowa. Kwartalnik Geologiczny, 28, 1, 39-58.

Sobotka J., 2005. Wibrostymulowane potencjały PS obserwowane nad złożami węglowodorów. Nafta-Gaz, 61, 3, 103-108.

Topographic map, Bolków sheet (462.13), 1: 25 000, [on-line:] https://pzgik.geoportal.gov.pl/semantic-metadata/topo/ dataset/100a878f-2a44-4a41-8a1a-6809c59a04ed.html. 